\title{
NEW APPROACH ON ENVIRONMENTAL FLOW ASSESSMENT OF MOUNTAIN STREAMS IN THE REPUBLIC OF MACEDONIA
}

\author{
Ivan Blinkov \\ Department of Land and Water, Faculty of Forestry, Ss. Cyril and Methodius University, \\ Skopje, Republic of Macedonia \\ e-mail: blinkov@sf.ukim.edu.mk; ivanblinkov12@yahoo.com
}

\begin{abstract}
Environmental flow is defined as the flow that is necessary to ensure the existence of habitats in a stream. According to the practice in Macedonia, environmental flow is $10 \%$ of mean annual flow but flow variation is significant and this approach could generate doubts for engineers. The final aim of this study was to be recommended the most appropriate method for this engineering purpose in Macedonia. This study consists of two parts: a) evaluation of the most used world methods in national conditions, and b) defining of environmental flow using previously selected method on case study. The proposed approach was tested for the "Dragor" water supply system. Using basically Tennant approach, and making modification according to the regional circumstance related to hydrological regime, environmental flow was calculated for 3 different periods of flow values that's follow the hydrogram.
\end{abstract}

Key words: environmental flow assessment; mountain stream

\section{INTRODUCTION}

With the enforcement of the new Water Law in the Republic of Macedonia (RM) that is in accordance with the European Water Frame Directive (WFD) (2000/60/EC), the Ministry of Environment and Physical Planning (MOEPP) is expecting a large number of applications for water usage permits. Since the legal instrument of water use permit is new in Macedonia and there is a lack of experience in enforcement, the MOEPP needs a precise support regarding law enforcement. In accordance with the WFD requirements, this also includes defining of environmental flow. Environmental flows describe the quantity, timing, and quality of water flows required to sustain freshwater and estuarine ecosystems and the human livelihoods and wellbeing that depend on these ecosystems [1].

Due to the natural conditions in the country, water flows significantly vary and the research by Škoklevski Ž. [2] showed significant variation even of the river of Vardar flow $\left(Q_{\min }=6,2 \mathrm{~m}^{3} / \mathrm{s}\right.$ - year 1952; $Q_{\max }=1310 \mathrm{~m}^{3} / \mathrm{s}$ or $1595 \mathrm{~m}^{3} / \mathrm{s}$, year 1962). On the other hand, the small stream flow is more unstable.
According to the practice in water sector in the Republic of Macedonia, minimal acceptable water flow (environmental flow) is defined as $10 \%$ of the mean annual flow. This is the simplest conservative approach that very often causes problems in practice because of the great variety of water flow. This approach should be improved or change with more pragmatic and precise method.

That was a reason for launching this study. The general aim of this study was the selecting/development of the most appropriate method for environmental flow assessment in the RM and the testing its applicability on a case study. The study consists of two parts: selecting of a most appropriate approach and testing of the selected method.

Objectives of the first part of the study were:

- Analyzing current methods in the world and needed data;

- Defining available data in the RM;

-Evaluation of the applicability of these methods in national conditions.

Subject of the second part is applicability of Tennant method in Macedonian conditions through case study. 
Objectives of the second parts of the study were:

- Defining various flows using geospatial hydrology methods and approaches; proaches;

- Defining environmental flow using few/ap-

- Comparative analysis between results obtained by other methods and proposed approach.

\section{METHODOLOGY}

Research methodology was adapted to the objective needs. Regarding the defining of the most appropriate method for environmental flow assessment (EFA), several criteria were set before starting the work. The new method/approach should satisfy the following needs: to be aimed for defining environmental flow of mountain streams; to be appropriate to water resource planning and practice; data to be easy available; to be simple without requirement for high scientific knowledge; assessment to be fast; to be cheap.

The qualitative method was used for analyzing the applicability of the most world used methods in national conditions. Evaluation of data availability for usage of various methods was done using qualitative method. For economic evaluation of the methods were used foreign experiences.

The case study region covers "Dragor" water supply system. Water received in filter station "Dihovo", originates from 3 sources: "Dragor" system (managed by PCE Bitola); surface water collector (managed by PE "Streževo" - Bitola); reservoir Streževo through main channel (managed by PE Streževo - Bitola). Maximal average daily water consumption in July and August is over $600 \mathrm{l} / \mathrm{s}$ although picks are near $900 \mathrm{l} / \mathrm{s}$. The study area is located on the east slopes of the Baba Mountain, upstream from the village of Nižepole and fully belongs to the Nationla Park "Pelister". It consists of four stream catchments that form the Dragor river. Crvena Reka river catchment covers the north part of the study area. Ezerska Reka river (Lak Potok) is located in the mid part, while Sapundjica (including Stara Buka catchment) covers the south part of the area. Total catchment area is $37,2 \mathrm{~km}^{2}$ and is distributed as follows: Crvena Reka $\left(12,99 \mathrm{~km}^{2}\right)$, Ezerska Reka $\left(3,85 \mathrm{~km}^{2}\right)$, Stara Buka $\left(2,66 \mathrm{~km}^{2}\right)$ and Sapundjica $\left(13,22 \mathrm{~km}^{2}\right)$. All natural conditions (topography elements, climate elements, geological and pedological structure, and vegetation cover) enable high values of flow, over $201 / \mathrm{s} \mathrm{km}^{2}$.

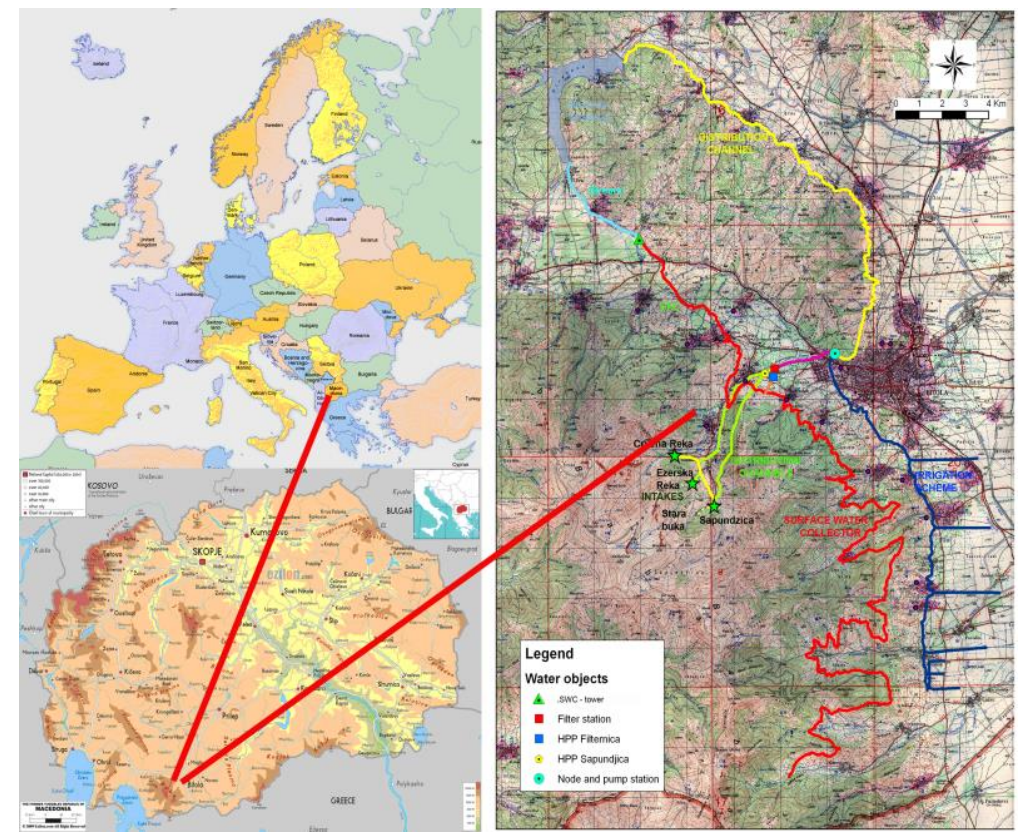

Figure 1. Study area location

Measuring data from the study area do not exist. A long-term hydrologic prediction in ungauged basins is one of the critical issues in the field of hydrologic calculations. Wang et al. [10] states that hydrologic analogy is an important method for long-term hydrologic prediction and hydrologic calculation in ungauged basins. There is a gauge station on the Dragor river (downstream from the village of Nižepole) but this data was not useful because significant amount of water has al- 
ready been used. In the vicinity, there are measuring stations on the rivers of Semnica and Brajčinska Reka. Brajčinska Reka is adjacent and was selected as a referent basin. The flow module was defined on the basis of a deep comparative analysis of factors affecting the flow between the study region and the selected reference catchment was defined flow module. This value was later used for calculation of minimal average and maximal flow using correction based on the comparative analyze.

Environmental flow was firstly calculated using original Tenant method. Results were compared with real hydrogram. Because of significant deviations was developed a new approach that follows the hydrogram variation more precisely then using Tennant method. This new approach was tested per month.

\section{THEORETICAL BACKGROUND}

There are a lot of methods for calculating the minimum (environmental) flow that is required for water habitats. Each method takes different properties of water habitat into account. That is why these methods depend on different assumptions. Different methods are used in different countries.

According to Tharme [3] there are more then 200 environmental flow assessment (EFA) methods. Pyrce [4] classified all methods in 4 groups: a) hydrological methods; b) hydraulic rate methods; c) habitat simulation methods; d) holistic methods.

Using hydrological or so-called historical flow methods, environmental flow is calculated by using daily and monthly measurement values or using flow measuring data.

Hydraulic methods relate various parameters of the hydraulic geometry of a watercourse channel to discharge. The most commonly used hydraulic method is the wetted perimeter. The wetted perimeter method is the simplest of the field survey-based, site-specific techniques that allows the minimum instream flow of a watercourse to be calculated, it should be noted that the wetted perimeter technique includes no explicit representation of the aquatic habitat, The wetted perimeter of a watercourse is defined as the length of the line of intersection of the channel wetted surface with a cross sectional plane normal to the direction of the flow [5].

Habitat rating methodologies use changes in simple hydraulic variables, such as wetted perimeter or maximum depth, usually measured across single, flow-limited river cross-sections (commonly riffles), as a surrogate for habitat factors known or assumed to be limiting to target biota [6]. According to Hatfield, T. et al [7] habitat rating methods provide the most complex and the most flexible approach to environmental flow assessments. These methods provide information on how habitats change with flow for instream uses, either biological or recreational. The most exposed habitat-rating method is Instream Flow Incremental Methodology

Holistic methodologies aim to address the water requirements of the "riverine ecosystem" rather than the needs of only a few taxa. They share a common objective - to maintain or restore the flow-related biophysical components and ecological processes of in-stream and groundwater systems, floodplains and downstream receiving waters (e.g. terminal lakes and wetlands, estuaries and near-shore marine ecosystems). There are numerous methods that belong to this group as follow: Holistic Approach, Building Block Methodology, Scientific Panel Assessment Method, Habitat Analysis Method, Benchmarking Methodology etc.

Each method has it own advantages or disadvantages. Some methods are based only on hydrological data, some methods are based only on hydraulic data. On the other hand, there are methods that encompass hydrological, hydraulic and biological data. Accuracy level is inversely proportional with needed work time and costs of works for defining environmental flow.

\section{RESULTS AND DISCUSSION}

\section{Defining the most appropriate environmental flow assessment approach}

According to Stojov [8], State Hydrometeorological Service of the Republic of Macedonia has been performing regular hydrological monitoring on 110 Surface Stations since 1947. These stations are located on the biggest stream and usually in the lower part of the catchments. Data about flow in upstream/mountain parts of the streams are missing. However, there are various methods for defining values based on data from measuring in any similar referent point, in this case referent stream catchment. Biological data (data about fishes, macrozoobenthos and florae taxa) generally are very limited.

Generally, hydrological methods characterized as: simple, rapid, inexpensive desktop approaches, low data needs - primarily flow data, suitable for water resource planning purposes, enable potential for regionalization for different river ecotypes, suitable for low controversy situations but inflexible, with low resolution output, without direct ecological links that's usually absent or are limited. 
Habitat-ratio methods characterize as: high resolution habitat-flow relationships for target species; generate alternative e-flow scenarios for different species; advanced technical support, but focus on target species, not whole ecosystem; are not applicable for some ecosystem components; limited links with characteristics of flow regime; output restricted to flow-hydraulic habitat relationships; resource intensive relative to output and poor links with biological responses to flow change

Holistic methodologies characterize with: whole-ecosystem focus; generates alternative environmental flow scenarios for different ecological and social conditions; use of interdisciplinary ex- pert judgment in structured, consistent process; usable in data rich and data poor contexts (use of available techniques and understanding); explicit links with characteristics of flow regime and with biological and social responses to flow change.

De Fretas [9] presents approximate needed time and finances for defining environmental flow using various groups of methods. According to his research, hydrological methods need 1-5 months and 10000 USD; holistic expert-panel methods need 6-12 months and 100000 USD, while holistic - field studies and monitoring need 2-5 years and over 1000000 USD.

Table 1. Evaluation of analyzed methods/approaches for environmental flow assessment

\begin{tabular}{lcccccc}
\hline & $\begin{array}{c}\text { Needed } \\
\text { data }\end{array}$ & $\begin{array}{c}\text { Data availa- } \\
\text { bility }\end{array}$ & $\begin{array}{c}\text { Field } \\
\text { work }\end{array}$ & $\begin{array}{c}\text { Needed } \\
\text { knowledge }\end{array}$ & Costs & Precision \\
\hline Tennant - Montana & low & high & no & mid & low & low \\
Q90 & mid & mid & no & mid & low-mid & mid \\
Hydraulic methods & mid & mid & yes & mid & mid & mid \\
Habitat rating methods & high & low & yes & mid-high & high & mid \\
Holistic - expert panel driven & high & low & no & high & high & high \\
Holistic - measuring and modeling & high & low & yes & high & ext. high & ext. high \\
\hline
\end{tabular}

Taking into consideration all mentioned above, only group of hydrological methods satisfied all set requirements.

There are 2 subgroups of hydrological methods:

a) using directly daily/monthly measurement values (the most used is Tennant or TennantMontana method and its modifications);

b) using various low flow duration exceedance percentiles (e.g. Q95, Q75 - these known flows, known, are the average flow for any one day expected to be greater for 95 days or 75 in any 100 days or single low flow indices e.g. 7Q10, 7Q2, i.e. seven-day, consecutive low flow with a ten year return frequency; the lowest stream flow for seven consecutive days that would be expected to occur once in ten years).

The second group of methods needs daily flow data and the results are more reliable then results obtained by the first subgroup. All these methods depend on the availability of hydrological data.

According to the official price list of State Hydrometeorological service, there is a big difference between long-term daily data and long-term monthly data. Greater part of daily data in Macedonia is still in paper format and it increases the price.

Finally taking into account all mentioned above the only appropriate approaches for environmental flow assessment of mountain streams that fulfill all set criteria should be those based on Tennant meth- od. This method was developed for mid-western USA and has regional character. There are several modifications for use in other regions. The only needed data for usage of this method is long-term monthly flow. This type of data is available and cheap. The only disadvantages are that data are of limited use, and for some EFA should be used referent catchment where hydrological measuring exist.

The next step was the testing of the applicability of Tennant method on a case study.

\section{Case study: "Dragor" system-geospatial hydrology analyses}

Because measuring data for the study area do not exist, the method of hydrological analogy was used. For this purpose the data from Brajcinska Reka were used.

Hydrological station on Brajčinska Reka is located near the village of Nakolec and represents almost the whole catchment of Brajčinska Reka.

According to WFD needs and rules, within the project Prespa Lake Watershed Management Plan (PLWMP) Brajčinska Reka was delineated in 2 water bodies as follows: Brajčinska 1 that represents the upper part of Brajčinska Reka catchment on the altitude from $1120 \mathrm{~m}$ up to $2329 \mathrm{~m}$ asl. and Brajčinska 2. The flow in the upper part - Brajčinska 1 is significantly higher. 
Table 2. Monthly flow [m³/s] - Brajčinska Reka for period 1951-2004

\begin{tabular}{lccccccccccccc}
\hline Month & I & II & III & IV & V & VI & VII & VIII & IX & X & XI & XII & Annual \\
\hline Nro & 44 & 44 & 44 & 44 & 44 & 44 & 44 & 44 & 44 & 44 & 44 & 44 & 44 \\
Min & 0.2 & 0.2 & 0.3 & 0.7 & 0.6 & 0.1 & 0.1 & 0.1 & 0.1 & 0.1 & 0.1 & 0.2 & 0.3 \\
Max & 3.2 & 3.5 & 3.5 & 5.7 & 5.0 & 2.6 & 1.2 & 0.4 & 1.9 & 1.6 & 3.9 & 2.4 & 1.7 \\
Mean & 0.7 & 0.8 & 1.2 & 2.4 & 2.4 & 0.9 & 0.4 & 0.2 & 0.3 & 0.3 & 0.7 & 0.8 & 1.9 \\
Std/Dev & 0.5 & 0.6 & 0.6 & 1.0 & 1.2 & 0.6 & 0.2 & 0.1 & 0.3 & 0.3 & 0.7 & 0.5 & 0.3 \\
Variations & 0.8 & 0.8 & 0.5 & 0.4 & 0.5 & 0.6 & 0.6 & 0.4 & 1.1 & 0.8 & 1.0 & 0.7 & 0.2 \\
\hline
\end{tabular}

Source: KfW - [11]

Table 3. Mean monthly flow of Brajčinska Reka 1 - period 1951-2004

\begin{tabular}{ccccccccccccc}
\hline I & II & III & IV & V & VI & VII & VIII & IX & X & XI & XII & avg. \\
\hline 0.621 & 0.703 & 1.067 & 2.111 & 2.162 & 0.797 & 0.349 & 0.183 & 0.217 & 0.271 & 0.595 & 0.686 & 0.813 \\
\hline
\end{tabular}

Source: Prespa Lake Watershed Management Plan [12]
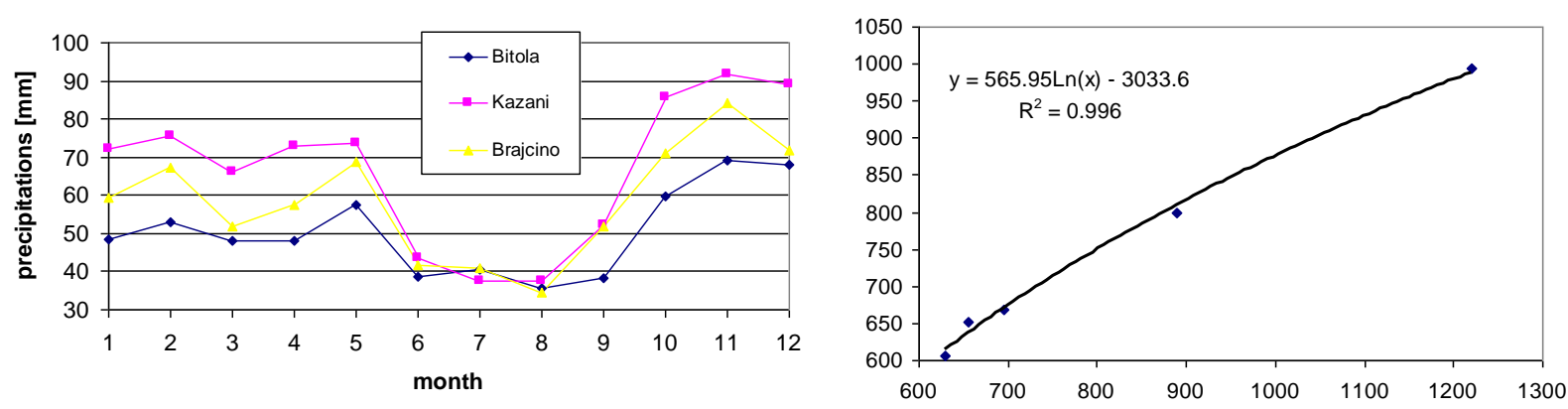

Figure 2. Correlation between altitude and rainfalls

With an aim to define the flow module of study catchments and the referent catchment, a deep analysis of site factor affecting flow was launched.

For defining of the correlation between rainfalls and altitude, a mathematical analysis was made. For this estimation data from gauge stations: Bitola, Kazani, Graešnica and Lopatica were used.

Estimated equation is $y=565,95 \operatorname{Ln}(x)-$ 3033,6 , where $y$ is annual sum of rainfall and $x$ is altitude. Coefficient of determination is $R^{2}=0,996$. It shows almost functional correlation. Mean precipitation on the catchment was defined using the following formula and the mean catchment altitude.

The next step was the developing of basic geospatial dataset and geospatial analysis.

Generally, relief type is mountainous and dissected with various streams. It also enables high values of flow module. Catchment shape of Brajcinska Reka is significantly positive to high flow then the other. Altitude difference is similar. Mean catchment slopes are almost the same, while stream bed slopes are similar. Calculated mean precipitation values are also almost the same.
Soil type distribution (cambisols and rankers) is similar. Cambisols occur in region with rainfall surplus but in terrains that permit surgical discharge of excess water. Cambisols have good structural stability, high porosity, good water holding capacity and good internal drainage. Rankers are skeletous and shallow with lower water capacity then cambisols. Within Brajčinska 1 catchment, semiporous rocks (Sse - quartz-quartz-sericite schists) dominate. Similar distribution is within the Stara Buka catchment. On the other hand non-porous rocks $(\gamma$-alkaline granites) dominate within other catchments. Appearance of porous Quaertenary deposits ( $\mathrm{gl} / \mathrm{fgl}$ - glacial, fluvuioglacial) is almost the same but is not significant.

According to land cover distribution (reclassified for hydrological needs), there is a significant difference. Water resistant land cover type dominates in Brajčinska 1, while semiresistant and low resistant land cover dominates within other catchments.

Taking into consideration all above, it can be concluded that catchments used for water abstrac- 
tion are very similar to the referent site - Brajčinska 1. It means that runoff module of Brajčinska 1, $q=21,5 \mathrm{l} / \mathrm{s} \cdot \mathrm{km}^{2}$, can be used as relevant to all other catchments.
Total catchment area of the study area is 3272 ha or $32,72 \mathrm{~km}^{2}$. Calculations were done using catchment area and the runoff module. Results are presented per and the whole area.
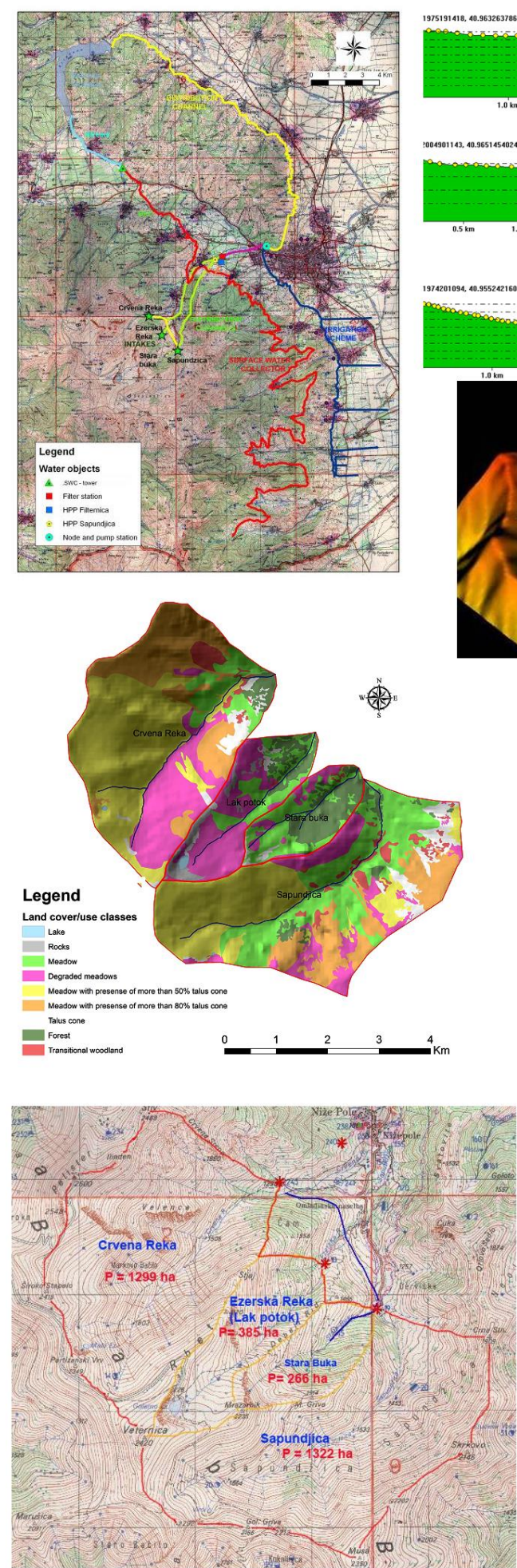
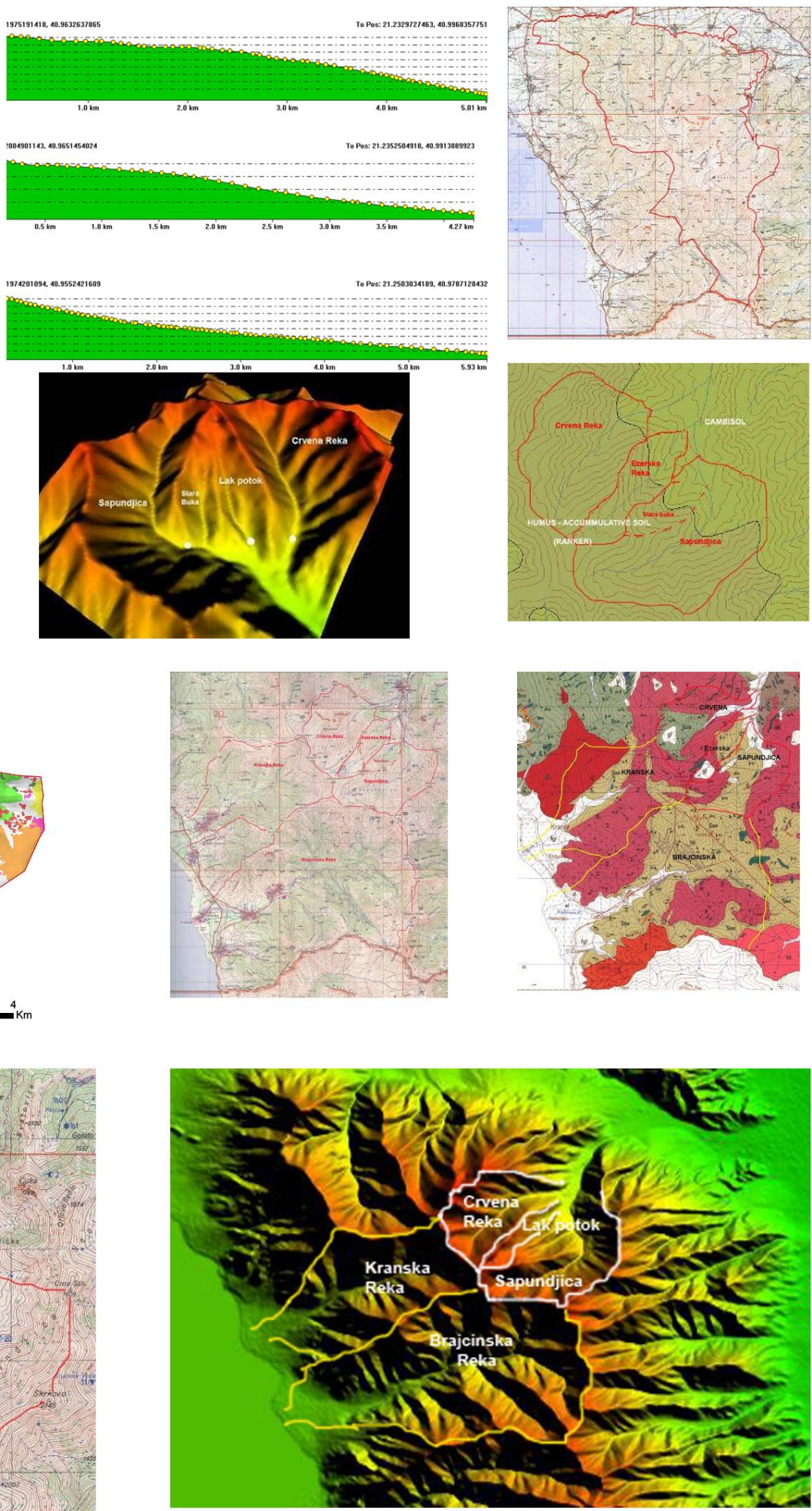

Figure 3. Basic geospatial database 
Table 4. Comparison of site factors affecting flow

\begin{tabular}{|c|c|c|c|c|c|c|}
\hline & Element & Brajčinska 1 & Crvena Reka & Lak Potok & Sapundjica & Stara Buka \\
\hline \multirow[t]{2}{*}{$A\left[\mathrm{~km}^{2}\right]$} & Catchment area & 37.75 & 12.89 & 3.85 & 13.22 & 2.66 \\
\hline & Catchment shape & trapeze & squatty & elongated & elong-squar & elongated \\
\hline$N_{\min }[\mathrm{m}]$ & Minimal altitude & 1120 & 1296 & 1289 & 1276 & 1276 \\
\hline$N_{\max }[\mathrm{m}]$ & Maximal altitude & 2329 & 2600 & 2420 & 2420 & 2235 \\
\hline$N_{a v g}[\mathrm{~m}]$ & Mean altitude & 1785 & 1986 & 1902 & 1852 & 1642 \\
\hline$\Delta N[\mathrm{~m}]$ & Altitude difference & 1191 & 1303 & 1129 & 1144 & 1059 \\
\hline$I[\%]$ & Mean slope & 42.12 & 45.12 & 38,05 & 40.26 & 42.86 \\
\hline $\mathrm{Jb}[\%]$ & Bed slope & 18 & 22 & 24 & 19 & 19 \\
\hline$P[\mathrm{~mm}]$ & Precipitations & 1204 & 1264 & 1240 & 1225 & 1157 \\
\hline \multirow{5}{*}{$\begin{array}{l}\text { Impervious } \\
\text { - ness }\end{array}$} & Soil type & $\mathrm{C}, \mathrm{R}$ & $\mathrm{C}, \mathrm{R}$ & $\mathrm{C}, \mathrm{R}$ & $\mathrm{C}, \mathrm{R}$ & $\mathrm{C}, \mathrm{R}$ \\
\hline & Rock type & Sse,$\gamma$, & $\gamma, \mathrm{Sco}, \mathrm{fgl}$, & Sse,$\gamma$, fgl, & Sse, $\gamma$, fgl & Sse, $\gamma$, fgl \\
\hline & Catchment & $\mathrm{NP}-0.15$ & $N P-0.6$ & $\mathrm{NP}-0.65$ & $N P-0.5$ & $\mathrm{NP}-0.1$ \\
\hline & Distribution per po- & $S P-0.75$ & $\mathrm{SP}-0.3$ & $\mathrm{SP}-0.25$ & $\mathrm{SP}-0.4$ & $\mathrm{SP}-0.7$ \\
\hline & rosity classes & $\mathrm{P}-0.1$ & $\mathrm{P}-0.1$ & $\mathrm{P}-0.1$ & $\mathrm{P}-0.1$ & $\mathrm{P}-0.2$ \\
\hline \multirow{4}{*}{$\begin{array}{l}\text { Catchment } \\
\text { distribution } \\
\text { per land } \\
\text { cover }\end{array}$} & Forests & 55.05 & 2.23 & 12.59 & 2.91 & 39.13 \\
\hline & Grassland/woodland & 44.95 & 69.98 & 72.46 & 74.86 & 57.12 \\
\hline & Bareland & 0.00 & 27.78 & 13.81 & 22.21 & 3.74 \\
\hline & Other (lakes) & 0.00 & 0.05 & 1.13 & 0.02 & 0.00 \\
\hline
\end{tabular}

Table 5. Calculated average monthly flow on the whole system area

\begin{tabular}{ccccccccccccc}
\hline Month & I & II & III & IV & V & VI & VII & VIII & IX & X & XI & XII \\
\hline$Q_{\text {avg }}[1 / \mathrm{s}]$ & 537 & 608 & 923 & 1826 & 1871 & 690 & 302 & 158 & 188 & 235 & 515 & 594 \\
\hline
\end{tabular}

Table 6. Calculated monthly minimal, average and maximal flow (discharge) per catchment [1/s]

\begin{tabular}{|c|c|c|c|c|c|c|c|c|c|c|c|c|}
\hline & \multicolumn{3}{|c|}{ Crvena Reka } & \multicolumn{3}{|c|}{ Lak Potok } & \multicolumn{3}{|c|}{ Stara Buka } & \multicolumn{3}{|c|}{ Sapundjica } \\
\hline & $Q_{\min }$ & $Q_{a v g}$ & $Q_{\max }$ & $Q_{\min }$ & $Q_{a v g}$ & $Q_{\max }$ & $Q_{\text {min }}$ & $Q_{a v g}$ & $Q_{\max }$ & $Q_{\text {min }}$ & $Q_{a v g}$ & $Q_{\max }$ \\
\hline & {$[1 / \mathrm{s}]$} & {$[1 / \mathrm{s}]$} & {$[1 / \mathrm{s}]$} & {$[1 / \mathrm{s}]$} & {$[1 / \mathrm{s}]$} & {$[1 / \mathrm{s}]$} & {$[1 / \mathrm{s}]$} & {$[1 / \mathrm{s}]$} & {$[1 / \mathrm{s}]$} & {$[1 / \mathrm{s}]$} & {$[1 / \mathrm{s}]$} & {$[1 / \mathrm{s}]$} \\
\hline I & 48 & 215 & 768 & 14 & 65 & 230 & 10 & 43 & 154 & 48 & 215 & 768 \\
\hline II & 48 & 244 & 840 & 14 & 73 & 252 & 10 & 49 & 168 & 48 & 244 & 840 \\
\hline III & 67 & 370 & 840 & 20 & 111 & 252 & 13 & 74 & 168 & 67 & 370 & 840 \\
\hline IV & 168 & 730 & 1368 & 50 & 219 & 410 & 34 & 146 & 274 & 168 & 730 & 1368 \\
\hline $\mathrm{V}$ & 144 & 748 & 1200 & 43 & 225 & 360 & 29 & 150 & 240 & 144 & 748 & 1200 \\
\hline VI & 50 & 276 & 624 & 15 & 83 & 187 & 10 & 55 & 125 & 50 & 276 & 624 \\
\hline VII & 24 & 121 & 288 & 7 & 36 & 86 & 5 & 24 & 58 & 24 & 121 & 288 \\
\hline VIII & 24 & 63 & 96 & 7 & 19 & 29 & 5 & 13 & 19 & 24 & 63 & 96 \\
\hline IX & 26 & 75 & 456 & 8 & 23 & 137 & 5 & 15 & 91 & 26 & 75 & 456 \\
\hline$X$ & 24 & 94 & 384 & 7 & 28 & 115 & 5 & 19 & 77 & 24 & 94 & 384 \\
\hline XI & 31 & 206 & 936 & 9 & 62 & 281 & 6 & 41 & 187 & 31 & 206 & 936 \\
\hline XII & 38 & 238 & 576 & 12 & 71 & 173 & 8 & 48 & 115 & 38 & 238 & 576 \\
\hline Avg. & 58 & 282 & 698 & 17 & 84 & 209 & 12 & 56 & 140 & 58 & 282 & 698 \\
\hline
\end{tabular}

Case study: "Dragor" system - Environmental flow assessment

According to the current Macedonian practice, environmental flow represents $10 \%$ of mean annual flow. Calculated values using previous approach are as follows: Crvena Reka: 28 1/s, Lak
Potok 9 1/s, Stara Buka: 6 1/s, Sapundjica: 28 1/s, and total (from the whole area) - 71 1/s.

Tennant (or Montana) method appeal is in its simplicity easy to of use. Tennant method uses a percentage of the mean annual flow for two different six month periods to define conditions of flow related to fishery, wildlife, recreation and environmental resources [13]. 
Table 7. Calculated minimal ecological flow according to the original Tennant method [1/s]

\begin{tabular}{|c|c|c|c|c|c|c|c|c|c|c|c|c|}
\hline & \multicolumn{6}{|c|}{ October - March } & \multicolumn{6}{|c|}{ April - September } \\
\hline & $\%$ & Total & $\mathrm{CR}$ & LP & SB & SAP & $\%$ & Total & CR & LP & SB & SAP \\
\hline & $\mathrm{Q}_{\mathrm{avg}}$ & 568.70 & 225.78 & 66.92 & 46.24 & 229.78 & $\mathrm{Q}_{\mathrm{avg}}$ & 839.13 & 333.14 & 98.74 & 68.22 & 339.04 \\
\hline $\begin{array}{l}\text { Flushing or } \\
\text { maximum }\end{array}$ & 200 & 1137 & 452 & 134 & 92 & 460 & 200 & 1678 & 666 & 197 & 136 & 678 \\
\hline $\begin{array}{l}\text { Optimum } \\
\text { range }\end{array}$ & $60-100$ & 341 & 135 & 40 & 28 & 138 & $60-100$ & 503 & 200 & 59 & 41 & 203 \\
\hline Outstanding & 40 & 227 & 90 & 27 & 18 & 92 & 60 & 503 & 200 & 59 & 41 & 203 \\
\hline Excellent & 30 & 171 & 68 & 20 & 14 & 69 & 50 & 420 & 167 & 49 & 34 & 170 \\
\hline Good & 20 & 114 & 45 & 13 & 9 & 46 & 40 & 336 & 133 & 39 & 27 & 136 \\
\hline $\begin{array}{l}\text { Fair or } \\
\text { degrading }\end{array}$ & 10 & 57 & 23 & 7 & 5 & 23 & 30 & 252 & 100 & 30 & 20 & 102 \\
\hline $\begin{array}{l}\text { Poor or } \\
\text { minimum }\end{array}$ & 10 & 57 & 23 & 7 & 5 & 23 & 10 & 84 & 33 & 10 & 7 & 34 \\
\hline $\begin{array}{l}\text { Sever } \\
\text { degradation }\end{array}$ & $<10$ & 57 & 23 & 7 & 5 & 23 & $<10$ & 84 & 33 & 10 & 7 & 34 \\
\hline
\end{tabular}

CR - Crvena Reka, LP - Lak Potok, SB - Stara Buka, SAP - Sapundjica

According to the practice in the country, calculated flow of $71 \mathrm{l} / \mathrm{s}$ is lower then average minimal flow in four months (July, August, September and October). According to original Tennant method, not only $10 \%$ even $20 \%$, and $30 \%$ calculated environmental flow is lower than the measured flow in July, August and September. During the summer quartile, some streams and rivers have no or very little water in their bed. In a case of extreme dry period the flow value is lower then the calculated minimum flow.

\section{New approach for environmental flow assessment}

This approach belongs to hydrological methods and is based on Tennant (Tennant-Montana) method. The original Tennant method accepts "hydrological year" and divides it into two parts: October - March and April - September. According to the precipitation regime in the region and mostly in the Republic of Macedonia dominant values appear in May and somewhere additionally in November.

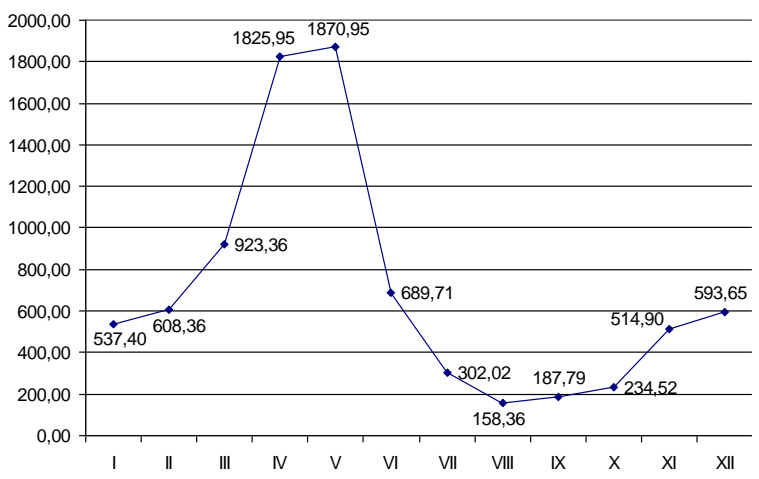

Figure 4. Variation of month flow of whole "Dragor" system
The hydrogram above shows three clearly separated groups of flow values:

Period 1 (P1) - mid values - November, December, January, February, March and June.

Period 2 (P2) - high values - April and May.

Period 3 (P3) - low values - July, August, September, October.

This leads to the conclusion that environmental flow should be defined according to the hydrological regime. Taking into consideration the above, environmental flows of study catchments were calculated for 3 different periods.

Using basically Tennant approach, and making modifications according to the regional circumstances related to hydrological regime, environmental flow was calculated as:

- for the low values period (P3), environmental flow is calculated as $30 \%$ (fair to good) of the mean period flow,

- for the mid values period (P1) calculated environmental flow was $15 \%$ (fair-good) of mean period flow or equal to month flow,

- for the high values period (P2), environmental flow is calculated as $10 \%$ (minimum) of mean period flow or equal to month flow.

Comparison of minimal flow $\left(Q_{\min }\right)$ in the study area (whole 3 catchments) and calculated minimal ecological flow (biological minimum) per month according to the practice in Macedonia, Tennant method and new approach, show that this new approach follows the hydrogram appropriately. If we compare absolute month minimum flow $Q_{\min }$ and calculated environmental flow $Q_{e n v}$ per month, only in excess cases in November the difference is higher then expected. However, in a case of extreme excess, then environmental flow is equal to 
the current measured flow. If we compare calculated environmental flow using new approach with Tennant descriptions then, for the period 1 (mid flow values) and period 2 (high flow values), it is evaluated between fair and good, while for the dry summer period (period 3 ) is evaluated as minimum. Comparison of calculated $Q_{e n v}$ using different approaches is presented on the Figure 5.

Table 8. Calculated environmental flow $Q_{\text {env }}$, according to new approach

\begin{tabular}{lcccccccccccc}
\hline Stream & \multicolumn{3}{c}{ Crvena Reka } & \multicolumn{3}{c}{ Lak Potok } & \multicolumn{3}{c}{ Stara Buka } & \multicolumn{3}{c}{ Sapundjica } \\
\hline Period & P1 & P2 & P3 & P1 & P2 & P3 & P1 & P2 & P3 & P1 & P2 & P3 \\
\hline \% of $Q_{\text {avg }}$ & 15 & 10 & 30 & 15 & 10 & 30 & 15 & 10 & 30 & 15 & 10 & 30 \\
$Q_{\text {avg }}[1 / \mathrm{s}]$ & 258 & 739 & 88 & 78 & 222 & 27 & 52 & 148 & 18 & 258 & 739 & 88 \\
$Q_{\text {min }}[1 / \mathrm{s}]$ & 47 & 156 & 25 & 14 & 47 & 7 & 9 & 31 & 5 & 47 & 156 & 25 \\
$Q_{\text {env }}[1 / \mathrm{s}]$ & 39 & 74 & 26 & 12 & 22 & 8 & 8 & 15 & 5 & 39 & 74 & 26 \\
\hline
\end{tabular}

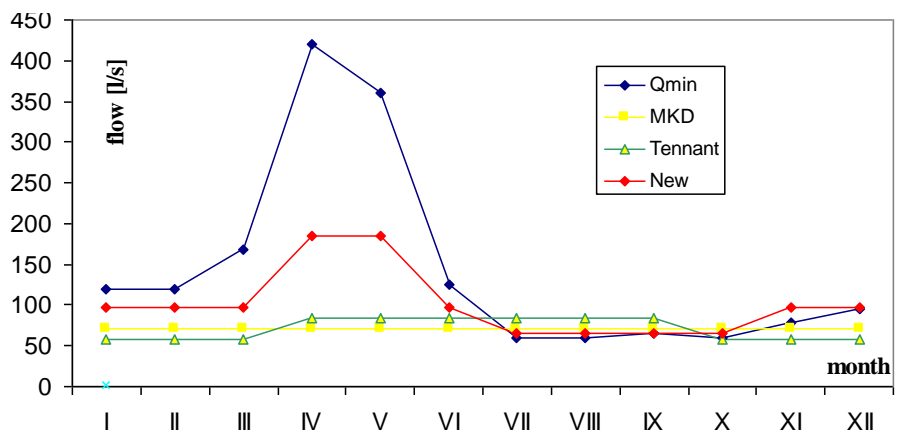

Figure 5. Comparison of $Q_{e n v}$ calculated by different approaches for the whole "Dragor" system

\section{CONCLUSIONS}

According to the available data, knowledge, needed time and financial resources, TennantMontana method is the most appropriate method for environmental flow assessment. Because of absence of measured hydrological data, calculation of average flow should be carried using hydrological analogy using deeper analysis of factors affecting flow on a study area and possible referent catchments.

Case study Dragor shows that direct usage of Tennant method is not fully in accordance to hydrological regime of studied mountain streams. For this purpose it is necessary firstly to analyze in details the hydrological regime and to define periods with various flow (low, mid, high) on the hydrogram. Using basically Tennant approach and making modifications according to the regional circumstance related to hydrological regime, environmental flow was calculated as:

- for the low values period (P3), environmental flow was calculated as $30 \%$ (excellent) of the mean period flow,

- for the mid values period (P1) calculated environmental flow was $15 \%$ (fair-good) of mean period flow or equal to month flow and
- for the high values period (P2), environmental flow was calculated as $10 \%$ (minimum) of mean period flow or equal to month flow.

This new approach should be used for environmental flow assessment of all mountain streams in the Republic of Macedonia.

Acknowledgment. This study was prepared as a part of the: Project: "Advisory Services for the Implementation of the Macedonian Water Law" (02.3515.0023.00), Deutsche Gesellschaft für Technische Zusammenarbeit (GTZ) GmbH represented by German Development Cooperation GTZ, Coordination Office Macedonia; Sub-project: "Preparation of the survey for the zones of water protection (proposal) and statement for application concerning permit for water abstraction "Dragor" system - Bitola, carried out by GTI - Geotehnički inženering, Skopje, 2011.

\section{REFERENCES}

[1] IWC, The Brisbane Declaration (2007), http://www.watercentre.org/news/declaration, 11.2.2014

[2] Z. Škoklevski, Vardar River through Skopje (Вардар низ Скопје), Water fund, GTZ, Skopje, (2000), pp. 112-113.

[3] R. E. Tharme, A global perspective on environmental flow assessment: emerging trends in the 
development and application of environmental flow methodologies for rivers. River Research and Applications 19, (2003) pp. 397-441. http://onlinelibrary.wiley.com/doi/10.1002/rra.736/ 3.2.2014.

[4] R. Pyrce, Hydrological Low Flow Indices and their Uses, report, WSC Report No. 04-2004 Watershed Science Centre, Trent University, Peterborough, Ontario (2004), pp. 1-37 http://mammoth.trentu.ca/iws/documents/LowFlo wOntRpt2004.pdf 10.1.2014.

[5] Handbook for the Assessment of Catchment Water Demand and Use, Department for International Development (DFID) of the UK Government (2003), pp. 20-39.

[6] A. H. Arthington, R. E. Tharme, S. O. Brizga, B. J. Pusey, M. J. Kennard, Environmental Flow Assessment with Emphasis on Holistic Methodologies, Proceedings of the Second International Symposium on the Management of Large Rivers for Fisheries, Sustaining Livelihoods and Biodiversity in the New Millennium, 11-14 February 2003, Phnom Penh, Kingdom of Cambodia, Edited by Robin L. Welcomme and T. Petr, Volume 2 (2003), pp. 37-66, http://www.fao.org/docrep/007/ad526e/ad526e07. $\underline{\mathrm{htm}}, 10.1 .2014$.

[7] T. Hatfield, N. Wright, S. Buchanan and S. Faulkner, A Review of Environmental Flow Assessment Methods for Application to Northeastern British Columbia. Consultant's report prepared for the Canadian Association of Petroleum Producers by Solander Ecological Research Ltd. and Ecofish Research Ltd (2012), pp. 1-96.

http://www.capp.ca/getdoc.aspx?DocId=219634\& DT=NTV 10.1.2014.
[8] V. Stojov, Through modernization of the hydrological monitoring towards improved water forecast, BALWOIS Conference 2010, 25-29 May 2010, Ohrid, Macedonia (2010).

http://balwois.com/?s=stojov\&post_type=k9proce eding 15.2.2014.

[9] G. K. De Freitas, Methods and tools for defining Environmental Flows, GEF IW:LEARN Regional Workshop on Application of Environmental Flows in River Basin Management, Foz do Iguaçu, Brasil, February, 11-15, (2008).

http://iwlearn.net/publications/1l/methods-andtools-for-defining-environmental-flows-de-freitas

[10] W. Wang, S. Hu, Y. Li, S. Cao, "How to Select a Reference Basin in the Ungauged Regions. "Journal of Hydrology Engineering, 18 (8), pp. 941947 (2013).

[11] KfW Feasibility Study - Project Preparation \& Development of the Transboundary Prespa Park Project, Part V: Hydrology Report, Annex Water Resources Data, GFA Consulting Group GmbH responsible persons: Dr. Heinz-Wilhelm Strubenhoff and Conrad Graf Hoyos (2005).

[12] UNDP-GEF-GTI project: Prespa Lake Watershed Management Plan, Reference No.: RFQ 50/2009, Technical report 2: Identification of the major watershed management issues in Prespa Lake Watershed, I. Kaevski, S.Spirovska (part: Hydrology and water balance model) (2010).

[13] D. Maunder, B. Hindley, Establishing Environmental Flow Requirements - synthesis report (2005), pp. $1-77$.

http://conservation-ontario.on.ca/projects/ flow.html

\title{
НОВ ПРИСТАП ЗА ПРОЦЕНА НА МИНИМАЛНИОТ ПРОТОК НА ВОДА КАЈ ПЛАНИНСКИ ВОДОТЕЦИ ВО РЕПУБЛИКА МАКЕДОНИЈА
}

\author{
Иван Блинков
}

\author{
Универзитет „Св. Кирил и Методиј“ во Скопје, Шумарски факултет, \\ Оддел за земјиште и вода, 1000 Скопје, Република Македонија
}

\begin{abstract}
Минимален прифатлив проток на вода (биолошки минимум) се дефинира како проток што е потребно да се обезбеди заради постоење на живеалиштата во водотеците. Во практиката во Македонија, минимален прифатлив проток на вода се дефинира како $10 \%$ од просечниот годишен проток, но варијациите на протокот се значителни и овој пристап може да генерира сомнежи за инженерите. Крајната цел на оваа студија беше да се препорача најсоодветен метод/пристап за инженерска намена во Македонија. Оваа студија се состои од 2 дела: а) процена на употребилвост на најчесто користени светски методи во националните услови; и б) да се дефинира минималниот проток на вода според новиот пристап на студија на случај. Новопредложениот приод беше тестиран на системот за водоснабдување „Драгор“. Со користењето на основниот пристап на Тенант и негова модификација според регионалните услови поврзани со хидролошкиот режим, минималниот прифатлив проток е пресметан за 3 различни периоди согласно со вредностите на минималниот и просечниот проток кои го следат хидрограмот.
\end{abstract}

Клучни зборови: процена на минимален прифатлив проток; Тенант; планински водотек 